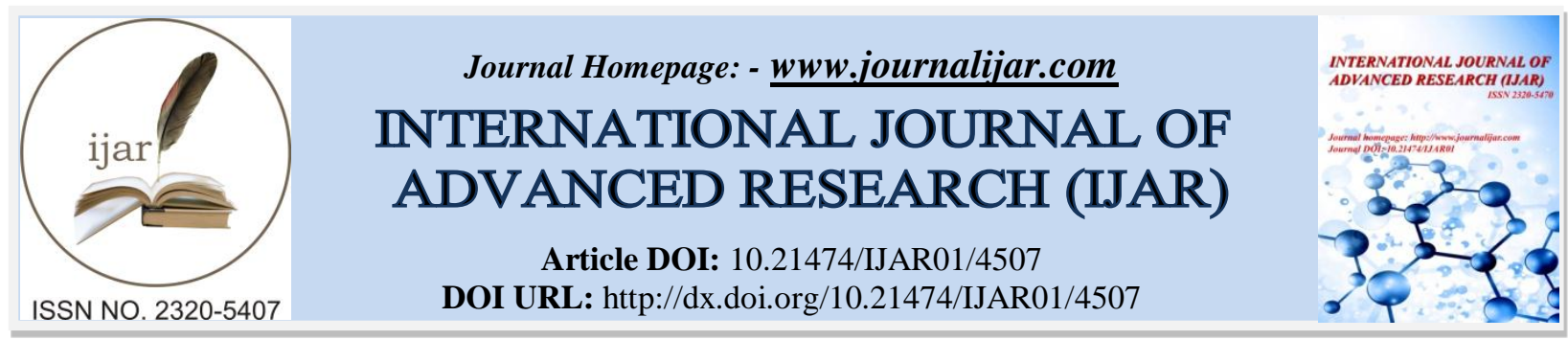

RESEARCH ARTICLE

\title{
PERFORMANCE ANALYSIS: LEADERSHIP PREDICTOR, COMPETENCY AND ORGANIZATIONAL CULTURE.
}

(Study On Urban Village in Bekasi City).

\begin{abstract}
Abdul Rivai ${ }^{1}$ and Suharto ${ }^{2}$.
1. Rector and Lecturer of Economic Faculty, Krisnadwipayana University, Jakarta Indonesia.

2. Lecturer of Economic Faculty, Krisnadwipayana University, Jakarta Indonesia
\end{abstract}

Manuscript Info
Manuscript History
Received: 17 April 2017
Final Accepted: 19 May 2017
Published: June 2017
Key words:-
Leadership, Competence, Organizational
Culture and Performance.

Leadership, Competence, Organizational
Culture and Performance.

\begin{abstract}
This study aims to analyze the influence of leadership, competence and organizational culture on the performance either partially or simultaneously in Urban Village in Bekasi City Region. The population of this study are all sub districts and their devices scattered in 12 districts in Bekasi City and identified 56 urban villages and 224 Urban Village. Determination of the number of samples refers to the distribution of cluster-based areas that are scattered based on the existing sub-districts in the city of Bekasi. Assuming that each urban village will be taken by 4 respondents, 1 urban village and 3 head of affairs, the total sample area is $35 \times 4=140$ urban village as expressed as sample area. Quantitative analysis method using path analysis, followed by determination analysis ( $\mathrm{R}$ Square), partial hypothesis testing ( $\mathrm{t}$ test) and simultaneous ( $\mathrm{F}$ test) with alpha 5 percent $(0,05)$. Before further analyzed first, the requirements analysis test is done. Analytical tool using SPSS version 21.0 for windows. The results showed that the leadership, competence and organizational culture partially and simultaneously have a positive and significant effect on the performance of Urban Village in Bekasi City Region.
\end{abstract}

Copy Right, IJAR, 2017,. All rights reserved.

\section{Introduction:-}

Rapid environmental changes marked by advances in information, changing tastes, demographic changes, economic fluctuations and other dynamic conditions require organizations to respond to the changes that occur to exist in global competition. Organizations often have to change the shape of their organizational structure to become an organization that can respond to changes that occur. Changes in the organization will have an impact on every individual within the organization.

One of the changes is the enactment of Law No. 32 of 2003 on regional autonomy. Law no. 32 this gives wide authority for local governments to develop regional potential for the welfare and prosperity of their people. However, the limited facilities and infrastructure as well as the support of human resources both from the side of government and society can be an obstacle for local governments in developing the potential of the region.

Urban village as a government institution directly in contact with the community must be able to provide good performance in an effort to develop the potential for the prosperity and prosperity of the people. Urban village as the 
spearhead of government at the lower level is required to have a reliable apparatus and can run the affairs of governance, development and social community. Besides, the Urban village apparatus acts as an apparatus capable of controlling the administrative organization of the Urban village by utilizing the supporting factors owned by the organization.

Departing from the above conditions, urban village officials have a dominant role and have a great responsibility in achieving the maximum outcomes of programs/activities proclaimed urban village specifically related to community empowerment. In other words, to realize and achieve these goals required the ability and performance of the maximum apparatus.

In performing its function, performance can not stand alone but related to factors, among others, leadership, competence, motivation, reward factor, cultural factor in work, commitment factor in work and many other factors. Armstrong (1998) describes a person's performance is influenced by four factors: 1) personal factors, including individual skills, competence, motivation, and recruitment, 2) qualified leadership factors and motivation, guidance and encouragement, 3) occupational system factors and facilities Given by the organization, 4) situational factors include changes and emphasis from internal and external factors.

Leadership has a very important role in improving performance for employees in order to provide maximum results. Until now, leadership is one of the issues in management that is still quite interesting to discuss until today. The mass media, both electronic and printed, often present opinions and talks about leadership. The role of leadership is very strategic and important for the achievement of the mission, vision and goals of an organization, is one motive that encourages people to always investigate the ins and outs associated with leadership (Raharjo et al, 2006). Some research results have been proven if leadership has influence on performance, among which are research conducted by Soegihartono (2012), Raharjo and Nafisah (2006), Ciptodihardjo (2014) and Yiing and Zaman (2009).

The other factors that are not less important in affecting a person's performance is competence. In the performance management competence more role in the dimensions of individual behavior in adjusting a job well. Competence is the ability and willingness to perform a task with effective performance. The importance of employee competence is to know critical ways of causality thinking, to understand good measurement principles, to ensure causal relationships and to communicate the results of strategic human resource performance to superiors (Dessler, 2009). Some research results also support performance influenced by competence, such as research conducted by Aima, $\mathrm{H}$ and Ali, H, et al (2017), Linawati and Suhaji (2012), Dhermawan, Sudibya and Utama (2012), and Albatros, E (2012) which states significantly and positively competence can affect performance.

Next another factor that can affect performance is organizational culture. Culture can be useful in organizations when each employee needs a brainstorming advice from his colleagues, but culture will be bad if the employees in the agency issued their opinions because the employees can work alone without the help of others (Nawawi, 2003). Organizational culture is a system of values that all members of the organization believe and are studied, implemented, and developed continuously that function as a whole system and can be used as a reference behave in the organization to create organizational goals that have been established (Djokosantoso, 2003).

The concept of organizational culture is one tool for improving performance, because organizational culture can influence the mindset, feelings and the way a person acts within an organization (Maslukhan, F, 2015). In addition, several previous studies have also proved that organizational culture can have an effect on performance, including those of Ahmad (2016), Judge, A., and Hadipapo, A. (2015), Taurisa, CM, and Ratnawati , I. (2012), Maslukhan, F. (2015) and Porwani, S. (2010) which states that organizational culture positively and significantly has an influence on performance. This means that by having a strong organizational culture, a person will be able to perform a task well, so it will be able to provide maximum results.

Based on the background and problems, the objectives of this research are:

1) Analyzing the influence of leadership on performance partially.

2) Analyzing the influence of competence on performance partially.

3) Analyze the influence of organizational culture on performance partially.

4) Analyzing the influence of leadership, competence, and organizational culture on performance simultaneously. 


\section{Literature Review:- \\ Performance:-}

Performance is a record of the results obtained from certain organizational / job functions over a period of time. According to Locke (2009) suggests that historically, performance is defined as a set of task statements derived from job descriptions, then judged to know the extent to which they perform the task. Meanwhile, according to Ruky (2002) performance is related to business, activities / programs initiated and implemented to plan and direct and control the performance of employees.

In performing its function, performance can not stand alone but relate to its supporting factors. According Mangkunegara (2014) as for the factors that affect the achievement of performance in the organization consist of two, namely individual factors and organizational environmental factors. Psychologically, normal individuals are individuals who have high integrity between psychic (spiritual) and physical (physical) functions. Given the high integrity of psychic and physical function, the individual has a good self concentration. This good concentration is the main capital of human individual to be able to manage and utilize his potential optimally in carrying out activities or daily work activities in achieving organizational goals.

While the environmental factors of the organization is very supportive for individuals in achieving work performance. Organizational environmental factors include clear job descriptions, effective work communication patterns, harmonious working relationships, respectful and dynamic work climate, career opportunities and work facilities are relatively adequate. Even if the environmental factors of the organization are less supportive, then for individuals who have a level of intelligence of the mind adequate with good emotional level, in fact he still can excel in work. This is for the individual, the organization's environment can be changed and can even be created by himself and is a booster, a challenge for himself in achieving in the organization.

Armstrong (1998) fully explains that the four factors that affect the performance are: 1) personal factors, including individual skills, competence, motivation, and commitment, 2) leadership factors, namely the quality of motivation, guidance and encouragement given by the leadership, 3) occupational system factors and facilities provided by the organization, and 4) situational factors, including changes and emphasis of internal and external factors.

According Caudron (1995) there are several indicators that need to be considered in assessing organizational performance, these dimensions include: 1) Work teams and information sharing are building block, 2) Provide the training and resources needed to do good job, 3) Provide measurement, feedback and reinforcement, 4) On going reinforcement, 5) Provide responsibility and authority, and 6) Flexible in internal procedure.

\section{Leadership:-}

Leadership within an organization determines the success or failure of an organization or organization and the leader is responsible for the failure of a job. A leader moves a human who has feelings and minds and a variety of types and their nature, then the issue of leadership can not be seen easily. The ability of a leader is a means to meet his needs depending on the skill and ability of the leader.

Fiedler explained that leadership is the ability to provide direction and coordination to subordinates (organizational members) in achieving organizational goals, as well as willingness to be the main responsibility of the activities of the group he leads (Hanafi, 2002). Further, Hanafi (2002) explains there are five essential leadership functions: 1) As a direction determiner, 2) As a spokesman, 3) As a communicator, 4) As a mediator, and 5) As an Integrator.

Basically a leader has different behaviors in regulating his members, and the behavior is called a leadership style. The style of leadership is thus the way a leader influences members and cooperates with various programs and predetermined ways. According Thoha (2001) suggests the type / style of leadership as follows.

1. Authoritarian style, is an authoritarian leader acting very directive, like to impose the will, do strict supervision, and does not provide opportunities for participation to subordinates.

2. Democratic style, is a leader who always encourages groups or subordinates to be active in the work, listening to advice and suggestions subordinates, leaders participate in the group.

3. Self-styled style (Laissez Faire), is the leader who gives absolute freedom to the group in the work, the leader is indifferent to the employee, the leader does not participate in the group. 
In general, according to Wahjosumidjo (2002) the indicators used to measure leadership are: 1) fair, 2) giving suggestion, 3) supporting the achievement of goals, 4) catalyst, 5) creating a sense of security, 6) as a representative of the organization, 7) Source of inspiration, and be respectful.

From the above indicator, it can be concluded that a leader has the nature and attitude that in essence can support achieved organizational goals that have been set previously. Because the ability of a good leader will succeed in overcoming various difficulties or problems faced by the organization and employees. This leads to an atmosphere such as subordinates feel guided, guided and assisted by leaders who at the end they feel happy to carry out its obligations.

\section{Competence:-}

Competence contains a deep and inherent personality section of a person with predictable behaviors in different circumstances and job tasks. The prediction of who performs well and less well can be measured from the criteria or standards used. Competence analysis is largely devoted to career development, but determining the level of competence is required to determine the effectiveness of expected levels of performance.

According to Boulter (1996) the level of competence is as follows: Skill, Knowledge, Self concept, Self Image, Trait and Motive. Skill or skill is the ability to perform a task well. Knowledge is information that a person has for a specific field. Social role is the attitudes and values a person has and highlighted in society (self-worth expression). Self image is a person's view of self, brand identity.

Competence is a fundamental characteristic of each individual associated with the referenced criteria of superior or effective performance in a job or situation. According to Spenser and spencer in Wibowo (2011) states that competence is the basic foundation of the characteristics of people and indicates how to behave or think, equalize the situation, and support for a long period of time.

The concept of competence must have a "Criterion Reference" to prove that the element of competence affects the good or bad of one's performance. Competence is the basic characteristic of a person with a cause-and-effect relationship with outstanding work performance or with work effectiveness and Dave Ulrich suggests that competence is the knowledge, skill or ability of the individual being demonstrated (Hutapea and Thoha, 2008).

The concept of competence is applied in various aspects of Human Resource Management. Competency Based Training, Competency Based Recruitment and Selection and Competency Based Payment were initially used. Then the last competence is integrated into the concept of Competency Based Human Resource Management (CBHRM) (Ruky, 2002).

According to Wyatt in Ruky (2002) competency is a combination of skills, knowledge, and attitude that can be observed and applied critically to the success of an organization and job performance as well as personal contribution of employees to the organization.

\section{Organization Culture:-}

Organizational culture is a system of shared meanings within an organization that determines in a higher level how employees act (Robbins, 1999). According Djokosantoso (2003) organizational culture is a system of values that are believed by all members of the organization and which are studied, applied, and developed continuously that serves as an overall system and can be used as a reference behave in the organization to create organizational goals that have been established. While Triguno (2000) argued that organizational culture is something of philosophy based on the view of life as values that become the nature, habits and driving forces, entrenched in the life of a community or organization group, then reflected from attitude to behavior.

On the other hand Schein in the journal Business Intelligence Journal August (Olu Ojo, 2009) says a broader organizational culture is a basic assumption pattern that is discovered, explored and developed by a group of people as a problem-solving experience. Adjustment to external factors and internal integration goes with meaning, so it is necessary to be taught to new members so that they have the right perception, thought and feeling in the face of the organization's problems. Culturally complete can be values, concepts, habits, feelings taken from the basic assumptions of an organization that are then internalized by its members. Can be a direct behavior when faced with problems or in the form of a distinctive character that is an academic image that can support a sense of pride in the 
profession that Studied. The learning environment itself is very supportive of imaging outside the organization, so it can look a culture will affect the forward and retreat of an organization. A professional character and strong culture will increase its performance in the organization and simultaneously improve its image.

Regarding the existence of culture within the organization, Schein (1992) states that organizational culture is at three levels or levels as follows: a) Artifacts, all organizational structures and processes that can be seen include: building form, employee appearance, communication mode, reward or punishment; b) value, at this level, both the organization and the members of the organization need strategy guidance. The purpose of the organization's leadership to act, including: participation, cooperation, leadership; c) The basic assumption, namely the number of beliefs or beliefs that members of the organization get assurance that they are received correctly in the right way, including: human relationships with humans, human relationships with activities, human relationships with time.

According to Robbins (1999) states there are seven dimensions of organizational culture as follows: 1) innovation and risk is the level where employees are encouraged to be innovative and risky; 2) attention to detail is the level at which employees are expected to display accuracy, analysis and attention to detail; 3) outcome orientation is the degree to which managers focus on results rather than on the techniques and processes used to achieve those results; 4) orientation to humans is the degree to which management decisions account for the effect of human outcomes within the organization; 5) team orientation is the degree to which work activities are organized around teams rather than individuals; 6) Aggressive is the degree to which people are aggressive and competitive rather than friendly and cooperate; 7) Stability is the degree to which organizational activities emphasize the effort to maintain the status quo instead of growth.

Meanwhile, according to Denison (1990), argued that there are four integrative principles about the interrelationships between organizational culture and the effectiveness of the company's work. These four principles are named as the four main traits concerning involvement, consistency, adaptability, and mission.

\section{Conceptual Framework:-}

Based on the formulation of the problem and the literature review described in the previous chapter, the conceptual framework of the study refers to relevant theories and previous research, in this case focused on the linkage of leadership factors, competence and organizational culture to the performance of urban village located in the area of Bekasi City .

As a comprehensive overview of the interrelationships between variables used in the research model, the following is presented in the conceptual framework of the study. Where the framework of the study can be described in (figure 1) as follows:

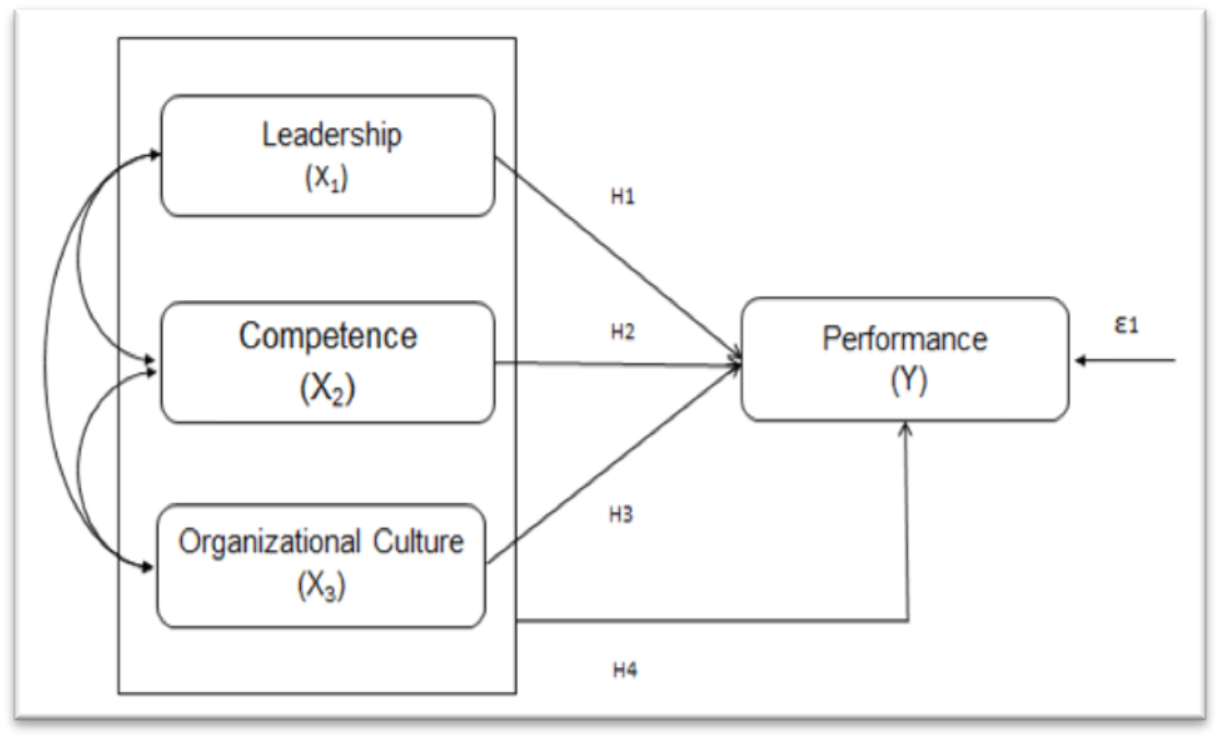

Figure 1:- Conceptual Framework 
Based on research objectives and theoretical reviews, the research hypothesis is:

1) Leadership affects performance partially

2) Competence affects performance partially

3) Organizational culture affects performance partially

4) Leadership, competence and organizational culture affect the performance of midwives simultaneously.

\section{Methods:-}

Approach in this research use quantitative approach with survey method and use path analysis technique. Path analysis is used to analyze the relationship patterns between variables with the aim to determine the direct or indirect effect of a set of independent variables (exogenous) to the dependent variable (endogenous).

The population of this study are all sub districts and their devices scattered in 12 districts in Bekasi City and identified 56 urban villages and 224 urban villages. Determination of the number of samples refers to the distribution of cluster-based areas that are scattered based on the existing sub-districts in the city of Bekasi. Assuming that each urban villages will be taken by 4 respondents, 1 head urban villages and 3 head of affairs, the total sample area is $35 \times 4=140$ urban villages expressed as sample area.

Prior to the analysis, a questionnaire instrument was tested with validity and reliability test and classic assumption test with normality, multicolinearity, and heterokedastisity test.

Path analysis is one of the analytical tools developed by (Dillon and Goldstein in Ali Hapzi and Limakrisna, N, 2013). Wright developed a method to determine the direct and indirect effects of a variable, where there are exogenous variables and variables that are affected (endogenous variables)

\section{Result and Discussion:-}

\section{Description of Research Variables:-}

Descriptive statistics used are mean, values often appear on respondent's answer (mode), median value, standard deviation and sample variance. The results of descriptive statistics in the study by using tools SPSS 21.0 as follows:

Table 1:- Descriptive Statistics of Research Variables

\begin{tabular}{|c|c|c|c|c|c|}
\hline \multicolumn{6}{|c|}{ Statistics } \\
\hline & & X1_Leadership & X2_Competence & X3_Organizational_Culture & Y_Performance \\
\hline \multirow[t]{2}{*}{$\mathrm{N}$} & Valid & 140 & 140 & 140 & 140 \\
\hline & Missing & 0 & 0 & 0 & 0 \\
\hline \multicolumn{2}{|c|}{ Mean } & 4.0243 & 4.0731 & 4.0129 & 4.1348 \\
\hline \multicolumn{2}{|c|}{ Std. Error of Mean } & .04605 & .04434 & .03615 & .03537 \\
\hline \multicolumn{2}{|c|}{ Median } & 4.0800 & 4.0769 & 4.0000 & 4.0000 \\
\hline \multicolumn{2}{|c|}{ Mode } & 4.08 & $3.92^{\mathrm{a}}$ & 3.94 & 4.00 \\
\hline \multicolumn{2}{|c|}{ Std. Deviation } & .54487 & .52467 & .42769 & .41851 \\
\hline \multicolumn{2}{|c|}{ Variance } & .297 & .275 & .183 & .175 \\
\hline \multicolumn{2}{|c|}{ Range } & 3.52 & 2.54 & 2.25 & 2.88 \\
\hline \multicolumn{2}{|c|}{ Minimum } & 1.28 & 2.46 & 2.75 & 2.13 \\
\hline \multicolumn{2}{|c|}{ Maximum } & 4.80 & 5.00 & 5.00 & 5.00 \\
\hline \multicolumn{2}{|c|}{ Sum } & 563.40 & 570.23 & 561.81 & 578.88 \\
\hline
\end{tabular}

Source: Output SPSS under 21.0 for windows

Before assessing the criteria of research variables in advance will be made scoring criteria. With the highest number of scores is 5, and the lowest number of scores is 1 . Classification of respondents score for research variables can be described in the stages of weighting scores with a score range $5-1 / 5=0.8$, as follows:

\begin{tabular}{|l|l|l|l|l|c|}
\hline \multicolumn{2}{|l|}{ Strongly Disagree } & Disagree & Simply Agree & Agree & Strongly agree \\
\hline \multicolumn{2}{|l|}{} & & & & \\
\hline 1 & 1,8 & 2,6 & 3,4 & 4,2 & 5 \\
\hline
\end{tabular}


Description of Leadership Variables $\left(\mathrm{X}_{1}\right)$

Descriptive results of leadership variables as shown in Table 1 above obtained an average value of 4,0243 including in the range $3.4-4.2$ are on the agreed criteria. The general respondent states that the leadership of urban village leaders in Bekasi City Region is relatively fair, able to give suggestions, support the achievement of goals, can be as a catalyst, able to create a sense of security, as an ambassador of the organization, source of information and be respectful.

Description of Competency Variable $\left(\mathrm{X}_{2}\right)$

Descriptive result of competence variable as seen in Table 1 above obtained the average value of 4,0731 including in the range 3,4-4,2 are in agreed criteria. Which explains that the respondents are more likely to agree that the competencies possessed by urban village employees in the Bekasi City Region. Where the respondent's assessment is aimed at aspects of character, attitudes and values, skills, and knowledge attached to the employees.

Description of Organizational Cultural Variables $\left(\mathrm{X}_{3}\right)$

Descriptive results of organizational culture variables as shown in Table 1 above obtained an average value of 4,0129 including in the range $3.4-4.2$ are on the agreed criteria. In general, the respondents agreed that the organizational culture in urban village in Bekasi City Region has been formally conducive. It is concluded that the respondents' answers are on average agreed on the aspect being asked related to employee involvement, consistency, and adaptation and mission.

Description of Performance Variables (Y)

Descriptive results of performance variables as shown in Table 1 above obtained an average value of 4.1348, including the range $3.4-4.2$ are on the agreed criteria. Which explains in general respondents agreed the performance of unban village in Bekasi City Region is also relatively good, it is responded by respondents with average answers that lead to agree and strongly agree. Respondents' responses are related to work team aspect and sharing of work information, preparing measurement, feedback on employee performance, reward and flexible rules.

\section{Classic assumption test:-}

From result of test which done by using SPSS 21.0 aid as a tool in this research is obtained result that the data in this research is normal distribution, it is proved from the result of significance value (Asymp Sig. 2-tailed) greater than 0,05 , that is $(0,560>0,05)$ so it can be concluded that the data in this study is normally distributed.

Then from the results of multicollinearity test known that the results of Tolerance value calculation shows no independent variable has Tolerance value less than 0.10 , which means there is no correlation between independent variables. In addition, the calculation of Variance Inflation Factor (VIF) value also shows the same thing there is no independent variable that has VIF value more than 10. So it can be concluded that there is no multicollinearity between Independent variables.

Furthermore, the results of heterocedastisity test known scatterplots seen that the points spread randomly and spread both above and below the number 0 on the Y-axis. It can be concluded that there is no heterocedastisity on the regression model, so that the regression model is appropriate to predict the use of accommodation services based on Input variable independent.

Based on the assumption test results, it has been fulfilled Requirements for further testing.

\section{Path Analysis:-}

This analysis is one option in order to study the dependence of a number of variables within the model. This analysis is a good method to explain if there is a large set of data to analyze and look for causal relationships.

To answer the purpose of research is done by using path analysis (path analysis) by using software tools SPSS version 21.0. The steps taken is to calculate the correlation between variables, then based on the results of calculations correlation matrix can be calculated path coefficient, as follows. 
Table 2:- Coefficients regression

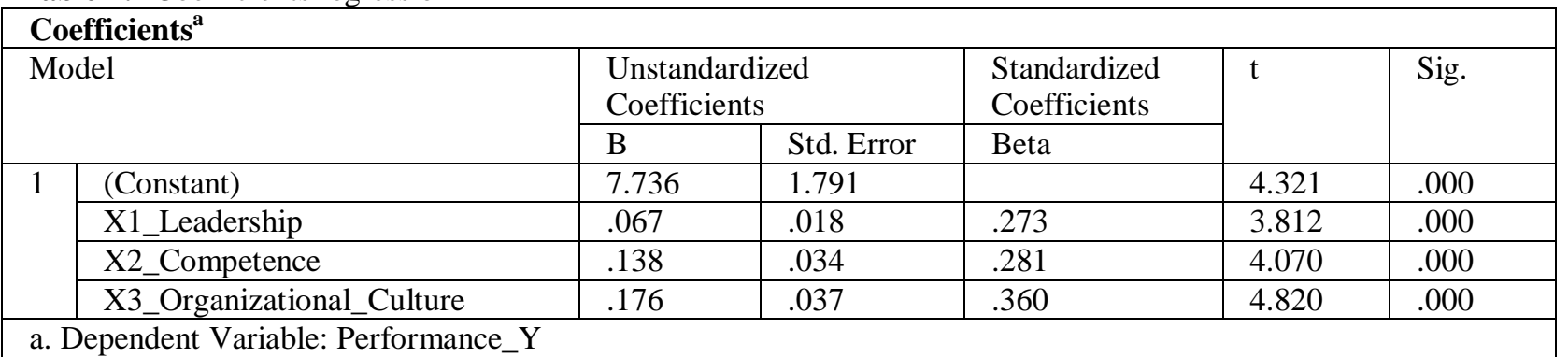

Source: Output SPSS under 21.0 for windows

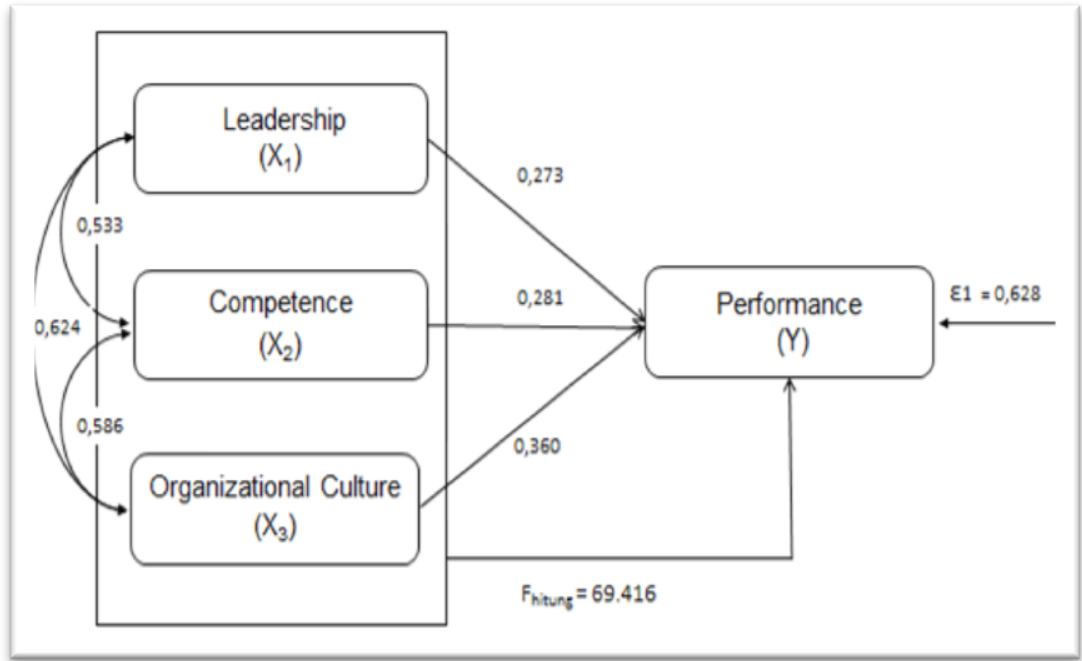

Figure 2:- Path Structure Analysis Results

To see the direct and indirect effects, it can be seen in the following table:

Table 3. Summary of Leadership Coefficient Leadership, Competence and Organizational Culture on Performance

\begin{tabular}{|l|l|l|l|l|l|l|}
\hline \multirow{2}{*}{ Variable } & \multirow{2}{*}{ Directly } & \multicolumn{1}{|l|}{ Indirect } & \multirow{2}{*}{ Sub Total } & Total \\
\cline { 3 - 6 } & & $\mathbf{X}_{\mathbf{1}}$ & $\mathbf{X}_{\mathbf{2}}$ & $\mathbf{Y}$ & & \\
\hline X1_Leadership & $7,45 \%$ & & $4,09 \%$ & $6,13 \%$ & $10,21 \%$ & $17,66 \%$ \\
\hline X2_Competence & $7,90 \%$ & $4,09 \%$ & & $5,93 \%$ & $10,02 \%$ & $17.92 \%$ \\
\hline X3_Organization Culture & $12,9 \%$ & $6,13 \%$ & $5,93 \%$ & & $12,06 \%$ & $24,96 \%$ \\
\hline Influence $\mathbf{X}_{\mathbf{1}}, \mathbf{X}_{\mathbf{2}}$, and Y Y & & & $60,54 \%$ \\
\hline Influence of Other Variables
\end{tabular}

Source: Output SPSS under 21.0 for windows is processed.

From the result of path analysis, it is obtained direct influence of leadership to performance equal to $7,45 \%$, competence to performance equal to $7,90 \%$, organizational culture to performance equal to 12,9 and total influence of leadership, competence and organizational culture to performance directly or not Direct at 60.54. The value describes the coefficient of determination $\mathrm{R}^{2}$ Square As shown in the following table.

Table 4:- Model summary

\begin{tabular}{|c|c|c|c|c|}
\hline \multicolumn{5}{|c|}{ Model Summary } \\
\hline Model & $\mathrm{R}$ & R Square & Adjusted R Square & Std. Error of the Estimate \\
\hline 1 & $.778^{\mathrm{a}}$ & .605 & .596 & 2.127 \\
\hline
\end{tabular}


$\mathrm{R}$ value of 0.778 shows a double correlation (leadership, competence and organizational culture) with performance. Considering the variation of $\mathrm{R}$ Square Value of 0,605 , it has significance of role or contribution of leadership variable, competence and organizational culture able to explain the performance variable equal to $60,5 \%$. While the rest of $39.5 \%$ is influenced by other variables that are not included in this model.

\section{Partial Effect Test Result (t test) and Simultaneous Influence (Test F):-}

Hypothesis testing aims to explain the characteristics of certain relationships or differences between groups or the independence of two or more factors in a situation, (Ali Hapzi, and Limakrisna, N., 2013). The partial effect test aims to test whether each independent variable significantly influences the partially bound variable with $\alpha=0.05$ and also the acceptance or rejection of the hypothesis. Partial test ( $t$ test) to answer hypotheses one and two of this study.

Table 5:- t Test Results (Partial)

\begin{tabular}{|l|l|l|l|}
\hline \multicolumn{2}{|l|}{ Model } & $\mathrm{t}$ & Sig. \\
\hline \multirow{3}{*}{1} & (Constant) & 4.321 & .000 \\
\cline { 2 - 4 } & X1_Leadership & 3.812 & .000 \\
\cline { 2 - 4 } & X2_Competence & 4.070 & .000 \\
\cline { 2 - 4 } & X3_Organizational_Culture & 4.820 & .000 \\
\hline
\end{tabular}

Source: Output SPSS under 21.0 for windows

From Table 5 above, it can be seen that $\mathrm{t}$ count the leadership variable $\left(\mathrm{X}_{1}\right)$ of 3.812, because the value of $\mathrm{t}$ arithmetic > t table $(3.812>1.656)$ then $\mathrm{H}_{0}$ is rejected and $\mathrm{H}_{1}$ is accepted, it means partially there is significant influence of leadership on performance. In addition to test based on significance test, can be seen from the output significance of 0.000 , because the level of significance more $<0.05(0.000<0.05)$ it can be concluded that leadership has a positive and significant impact on performance. Thus the first hypothesis is proved and acceptable.

Furthermore, in Table 5 above with the obtained $t$ count the competence variable $\left(\mathrm{X}_{2}\right)$ of 4,070 , because the value of $\mathrm{t}$ arithmetic > $\mathrm{t}$ Table $(4.070>1.656)$ then $\mathrm{H}_{0}$ rejected and $\mathrm{H}_{1}$ accepted, meaning that there is partially significant influence of competence on performance. In addition to test based on significance test, can be seen from the significance output of 0.000 , because the level of significance more $<0.05(0.000<0.05)$ it can be concluded that the competence has a positive and significant impact on performance. Thus the second hypothesis is proved and acceptable.

Furthermore, in Table 5 above with the obtained t count the organizational culture variable $\left(X_{3}\right)$ of 4820 , because the value of $\mathrm{t}$ arithmetic $>\mathrm{t}$ Table $(4.820>1.656)$ then $\mathrm{H}_{0}$ rejected and $\mathrm{H}_{1}$ accepted, meaning that there is partially significant influence of organizational culture on performance. In addition to test based on significance test, can be seen from the output significance of 0.000 , because the number of significance level more $<0.05(0.000<0.05)$ it can be concluded that organizational culture has a positive and significant impact on performance. Thus the third hypothesis is proved and acceptable.

To answer the fourth hypothesis that leadership, competence and organizational culture affect performance simultaneously can be seen from Table 6 below.

Table 6:- F test results simultaneously ANOVA $^{\mathrm{a}}$

\begin{tabular}{|l|l|l|l|l|l|l|}
\hline Model & Sum of Squares & Df & Mean Square & F & Sig. \\
\hline \multirow{4}{*}{1} & Regression & 942.574 & 3 & 314.191 & 69.416 & $.000^{\mathrm{b}}$ \\
\cline { 2 - 6 } & Residual & 615.562 & 136 & 4.526 & & \\
\cline { 2 - 6 } & Total & 1558.136 & 139 & & & \\
\hline
\end{tabular}

Source: Output SPSS under 21.0 for windows 
From the Anova or F test as shown in Table 6 with the obtained F count of 69.416 with the probability p-value of 0.000 , because the value $F$ count $>F$ table $(69.416>2.67)$ so it can be concluded that the null hypothesis $\left(\mathrm{H}_{0}\right)$ is rejected and Alternative hypothesis $\left(\mathrm{H}_{1}\right)$ is accepted, meaning there is a significant influence between leadership, competence and organizational culture together affect the performance. Thus the fourth hypothesis is accepted.

From the interpretation of the above data it can be discussed that:

1) Leadership on Performance:-

Leadership affects the performance significantly. The results of this study show the same results with research conducted by Ciptodihardjo (2014) which reveals leadership has a positive and significant impact on employee performance. The results of this study reveal that good leaders will be able to move their subordinates to work better for organizational progress. Next research conducted by Farida, Z (2012) also suggests leadership has a positive and significant influence on employee performance.

Leadership of a leader is indispensable in an organization because the advancement of an organization depends on how well leaders can play their part in order that the organization continues to live and thrive. Flippo in Dewi, S.P. (2012) argues that leadership can be defined as a behavioral pattern designed to integrate organizational and personnel interests to pursue multiple goals. For that a leader really need to pay attention to his leadership style in the process of influencing, directing the activities of members of his group and coordinate the goals of members and organizational goals so that both can be achieved.

\section{2) Competence on Performance:-}

Competence directly affects performance. The results of this study support or strengthen the existing theory, which states that the competence is the capacity that exists in a person who can make the person is able to meet what is required by the work in an organization so that the organization is able to achieve the expected work (Hutapea and Thoha, 2008 ). Besides, this study also shows the same results with research conducted by Linawati and Suhaji (2012), and Albatros, E (2012) which shows that the competence is very significant affect the performance of employees.

The findings provide an understanding that employee performance should prioritize the competence it has, meaning that the better the competence of employees in an organization will be better on the performance of the employees themselves. Therefore employees should continue to improve their competence and get used to perform all tasks in accordance with the main task and function.

\section{3) Organizational Culture on Performance:-}

Organizational culture has significant influence on performance. The results of this study show the same results with research that has been done Maslukhan, F. (2015) which suggests the organizational culture into a strong value system will grow a sense of ownership and improve morale, and it will impact on increased performance. Culture that exists within an organization has a purpose so that existing human resources within an organization able to change attitudes and behavior to improve its performance in terms of facing challenges in the future.

In addition, the results of this study are also in line with research conducted by Ahmad (2016), Judges, A., and Hadipapo, A. (2015), Taurisa, CM, and Ratnawati, I. (2012), and Porwani, S. ( 2010) where the results of his research states that the organizational culture in a positive and significant effect on performance. This means that by having a strong organizational culture, a person will be able to perform a task well, so it will be able to provide maximum results.

\section{4) Leadership, Competence and Organizational Culture on Performance:-}

Leadership, organizational culture and competencies together influence performance. The findings provide an understanding that the performance of an employee in carrying out the service must be supported by leadership, competence and organizational culture. This means that the better the leadership, competence and organizational culture within an organization, it will increasingly affect the performance of employees. Therefore, leadership, competence and good organizational culture that exist in urban village in Bekasi City must be able to provide good employee performance as well.

Performance consists of dimensions and or indicators: work teams and information sharing work; Preparing measurements, feedback on employee performance; appreciation; And flexible rules. Leadership consists of 
dimensions and or indicators: fair; Give suggestions; Support the achievement of objectives; catalyst; Create a sense of security; As ambassadors of the organization; Source information and be respectful. Competency consists of dimensions and or indicators: character; Attitudes and values; Skills; And knowledge. Organizational culture consists of dimensions and or indicators: involvement; consistent; Adaptation and mission.

\section{Conslussion And Sugestion:- Conclussion:-}

Based on the results and discussion then the conclusions of this study are:

1) Leadership has a positive and significant effect on performance partially. Leadership consisting of dimensions: fair; Give suggestions; Support the achievement of objectives; catalyst; Create a sense of security; As ambassadors of the organization; Source information and be respectful. It means that the better the role that a leader has in an organization, then it will give a positive work result to the improvement of employee performance.

2) Competence has a positive and significant effect on performance partially. Competencies consisting of dimensions: character; Attitudes and values; Skills; And knowledge. The better the competencies possessed by employees will be able to contribute positively to the employee performance spirit.

3) Organizational culture has a positive and significant effect on performance partially. Organizational culture consisting of dimensions: engagement; consistent; Adaptation and mission. The stronger positive organizational culture that is run, maintained and developed within an organization will be able to contribute positively to the performance of employees.

4) Leadership, competence and organizational culture have a positive and significant impact on performance. The better the leadership, competence and organizational culture that is owned in an organization, it will increasingly affect the performance of the organization.

\section{Sugestion:-}

Based on data analysis, statistical calculation process, empirical research model test and discussion of the results of the study conducted, submitted some suggestions as follows:

1) In the future, the leadership of urban village leaders in Bekasi City Region should be improved by always improving themselves constructively on aspects related to justice, the ability to give suggestions, support the achievement of goals, serve as a catalyst, able to create a sense of security, as Ambassadors of the organization, source of information and respect.

2) It should be in the future in the placement of employees in the urban village should be tailored to the educational background and also adjusted to the field of work of the employees themselves.

\section{References:-}

1. Ahmad. (2016). Influence of leadership Transformasional, Organizational culture and employee Motivation of Employee Job Satisfaction and its implication on PDAM employee performance in Banten Province. Dissertation of Pasundan University of Bandung.

2. Aima, Havidz and Ali Hapzi, et al., 2017. Model of Employee Performance: Competence Analysis and Motivation (Case Study at PT Bank Bukopin, Tbk Center). Quest Journals Journal of Research in Business and Management, ISSN (Online): 2347-3002. Volume 4 Issue 11 (2017) pp: 49-59. Www.questjournals.org

3. Albatros, E. (2012). Relation of Competence and Work Discipline to Performance of Educational Staff of Singaperbangsa Kerawang University. Journal of Management. Vol. 10 No. 1.

4. Ali, Hapzi., and Limakrisna, N. (2013). Research Methodology. Issue 1, Cet. 1, Deepublish, Yogyakarta.

5. Armstrong, Michael \& Baron, A. (1998). Performance Management: The New Realities. New York: Institute of Personel and Development.

6. Boulter. N, Dalziel, M and Hill. J. (1996). People and Competencies. London: Bidlles, Ltd.London

7. Caudron, Shari. (1995). "\ Create an Empowerment" Personal Journal, September, P.28-37

8. Ciptodihardjo, I. (2014). "Effect of Leadership, Motivation, Job Satisfaction Against Organizational Commitment and Employee Performance At Employees of PT. Smartfren, Tbk In Surabaya ". Journal of Management Dynamics, Vol. 5.

9. Denison, D.R. (1990). Corporate Culture and Organizational Effectiveness, New York: Wiley.

10. Dessler, G. (2009). Human Resource Management Tenth Edition. Jakarta: PT. Index.

11. Dhermawan, A.A.N.B., Sudibya, I.G.A., and Main, I.W.M. (2012). The influence of motivation, work environment, competence and compensation on job satisfaction and performance of employees in the Office 
of Public Works Office of Bali Province. Journal of Management, Business Strategy and Entrepreneurship Vol. 6, No. 2.

12. Farida, Z. (2012). Effect of Leadership Style, Satisfaction and Organizational Commitment to Employee Performance at Ministry of Religious Affairs of Jepara Regency. Dissertation.

13. Judges, A., and Hadipapo, A. (2015). Role of Leadership and Organizational Culture to Human Resource Performance in Wawotobi. Journal of Ecobics. Vol. 16, No. 1.

14. Hanafi, R. (2002). Introduction to Management. Yogyakarta: Graha

15. Hutapea, P and Thoha, N. (2008). Plus Competencies. Jakarta: PT Gramedia Pustaka Utama.

16. Linawati and Suhaji. (2012). The influence of motivation, competence, leadership and work environment on employee performance (Study at PT Herculon Carpet Semarang).

17. Locke, E. (2009). Leadership Essence: Four Keys to Lead with Success. Aris Ananda Translation. Jakarta: Mitra World.

18. Mangkunegara, A.A.A.P. (2014). Evaluation of HR Performance. Bandung: Refika Aditama.

19. Maslukhan, F. (2015). The Influence of Organizational Culture on Employee Performance (Case Study At Surakarta Islamic Hospital). Manuscript Publication of Muhammadiyah University of Surakarta.

20. Nawawi, Hadan. (2003). Human Resource Management for Competitive Business. Yogyakarta: Gajah Mada University Press

21. Porwani, S. (2010). The Influence of Organizational Culture on Employee Performance. Scientific journals. Vol. 11, No. 2.

22. Soegihartono, A. (2012). "The Influence of Leadership and Job Satisfaction on Performance with Mediation Commitment (at PT Alam Kayu Sakti Semarang)". Journal of Economic Partners and Business Management 3, No. 1.

23. Raharjo, S.T., and Nafisah, D. (2006). Analysis of Effect of Leadership Style on Job Satisfaction, Organizational Commitment and Employee Performance (Empirical Study at Religious Department of Semarang City Regency). Journal of Management \& Organization Studies, Vol. 3, No. 2.

24. Robbins, Stephen P and Coulter, Mary. (1999). Management. Jakarta: PT. Prenhallindo.

25. Ruky, U.S. (2002). Performance Management System: Perforance Management System, Practical Guide for Designing and Achieving Excellent Performance. Jakarta: PT. Gramedia Pustaka Utama.

26. Schein, E. H. (1992). Organizational Culture and Leadership (2nd.ed.). San Francisco:

27. Taurisa, C.M., and Ratnawati, I. (2012). Analysis of Organizational Culture Influence and Job Satisfaction To Organizational Commitment In Improving Employee Performance (Study at PT Sido uncul Kaligawe Semarang). Journal of Business and Economics (JBE). Vol. 19, No. 2.

28. Triguno. (2000). Work Culture. Jakarta: Golden Trayon Press Publisher.

29. Wahjosumidjo. (2002). Leadership and Motivation, Jakarta: Galia Indonesia.

30. Wibowo. (2011). Work management. Jakarta: PT. Raja Grafindo Parsada.

31. Yiing, L.H and Zaman, K. (2009). "The moderating effects of organizational culture on the relationships between leadership behaviour and organizational commitment and between organizational commitment and job satisfaction and performance". Leadership \& Organization Development Journal 30, no. 1. 